\title{
Spatial heterogeneity in near surface aerosol characteristics across the Brahmaputra valley
}

\author{
Binita Pathak ${ }^{1}$, Arup Borgohain ${ }^{2}$, Pradip Kumar Bhuyan ${ }^{1, *}$, Shyam Sundar Kundu ${ }^{2}$, \\ S Sudhakar ${ }^{2}$, Mukunda M Gogoi ${ }^{3}$ and Toshiniko TAKemura ${ }^{4}$ \\ ${ }^{1}$ Centre for Atmospheric Studies, Dibrugarh University, Dibrugarh 786 004, India. \\ ${ }^{2}$ North-East Space Application Centre, Umiam, Shillong, Meghalaya 793 103, India. \\ ${ }^{3}$ Space Physics Laboratory, Vikram Sarabhai Space Centre, Thiruvananthapuram 695 022, India. \\ ${ }^{4}$ Research Institute for Applied Mechanics, Kyushu University 6-1 Kasuga-koen, Kasuga, Fukuoka 816-8580, Japan. \\ ${ }^{*}$ Corresponding author.e-mail: pkbhuyan@gmail.com
}

In order to examine the spatial variability of the aerosol characteristics across the Brahmaputra valley, a land campaign was conducted during late winter (February 3-March 2) 2011. Measurements of particulate matter $\left(\mathrm{PM}, \mathrm{PM}_{10}, \mathrm{PM}_{2.5}\right.$ ) and black carbon (BC) concentrations were made onboard an interior redesigned vehicle. The length of the campaign trail stretched about $700 \mathrm{~km}$, covering the longitude belt of $89.97^{\circ}-95.55^{\circ} \mathrm{E}$ and latitude belt of $26.1^{\circ}-27.6^{\circ} \mathrm{N}$, comprising 13 measurement locations. The valley is divided into three sectors longitudinally: western sector (R1: $\left.89.97^{\circ}-91.75^{\circ} \mathrm{E}\right)$, middle sector (R2: $92.5^{\circ}-$ $\left.94.01^{\circ} \mathrm{E}\right)$ and eastern sector (R3: $\left.94.63^{\circ}-95.55^{\circ} \mathrm{E}\right)$. Spatial heterogeneity in aerosol distribution has been observed with higher $\mathrm{PM}_{10}$ and $\mathrm{PM}_{2.5}$ concentrations at the western and middle sectors compared to the eastern sector. The locations in the western sector are found to be rich in $\mathrm{BC}$ compared to the other two sectors and there is a gradual decrease in $\mathrm{BC}$ concentrations from west to east of the Brahmaputra valley. Two hotspots within the western and middle sectors with high PM and BC concentrations have been identified. The associated physico-optical parameters of $\mathrm{PM}$ reveal abundance of $\mathrm{PM}_{2.5}$ aerosols along the entire valley. High population density in the western and middle sectors, together with the contribution of remote aerosols, leads to higher anthropogenic aerosols over those regions. Spectral Radiation-Transport Model for Aerosol Species (SPRINTARS) slightly underestimates the measured $\mathrm{PM}_{10}$ and $\mathrm{PM}_{2.5}$ at the eastern sector while the model overestimates the measurements at a number of locations in the western sector. In general, $\mathrm{BC}$ is underestimated by the model. The variation of $\mathrm{BC}$ within the campaign trail has not been adequately captured by the model leading to higher variance in the western locations as compared to the middle and eastern locations.

\section{Introduction}

The discrete nature of aerosol sources (both natural and anthropogenic) and sinks, the variety of associated microphysical processes during their atmospheric residence time, and large scale synoptic processes in the atmosphere coupled with longrange transportation lead to large heterogeneity in spatio-temporal distribution, properties, and effects of aerosols. The aerosol abundance is highest near the surface as most of the aerosol sources (both natural and anthropogenic) are situated there. Study of their physico-optical and chemical parameters are essential for a better understanding of their role in the atmospheric processes. For reliable estimates of their impacts through

Keywords. $\mathrm{PM}_{10} ; \mathrm{PM}_{2.5}$; black carbon; SPRINTARS; CWT. 
regional scale climatological models, extensive observational data is necessary. On the other hand, the complex physical and chemical properties of aerosols are the major sources of uncertainty in the assessment of their impact on climate and environment. In order to reduce these uncertainties, accurate measurements of physical, optical, and chemical properties of the aerosols using multiplatform measurements (such as ground-based networks, ship, aircrafts, balloons, and satellites), multi-instrumented field experiments together with numerical modelling are of great importance (e.g., Kaufman et al. 2001). This, in particular, is essential in the south Asian region with all its natural diversities, high population density, diverse living habits, and the growing industrialization and urbanization (Moorthy et al. 2008). With this in view, several multi-platform, multi-institutional thematic field campaigns, viz., Indian Ocean Experiment (INDOEX) (Ramanathan et al. 2001), Arabian Sea Monsoon Experiment (ARMEX) (Moorthy et al. 2005), Integrated Campaign for Aerosols, Gases and Radiation Budget (ICARB) (Moorthy et al. 2008), Cloud-Aerosol Interaction and Precipitation Enhancement Experiment (CAIPEEX), Winter phase of Integrated Campaign for Aerosols, gases and Radiation Budget (W-ICARB) (e.g., Moorthy 2010) mostly over the oceans and land campaigns, viz., Land campaign-I (LC I) over southern and coastal India (Moorthy et al. 2005), Land campaign-II (LC II) over IndoGangetic plains, IGP (ARFI Report 2007-08) and over central Indian region (Jayaraman et al. 2006) have been conducted. Short-term campaigns such as those mentioned above have the advantage of measurements over an extended spatial domain within a short time span that brings out the special features of subregions within the campaign area, whereas point observations from any location provide high temporal span. However, the short duration and scattered distribution of surface point measurements during a campaign prevent collection of data required to extract robust spatial patterns.

In the regional characterization of aerosols over south Asia, a study from the north-eastern part of India assumes significance owing to its geographical position, being surrounded by east Asia, south east Asia, China and the mainland of India. In addition, the characteristic dense vegetation, vast water bodies, heavy rainfall pattern and the unique topography with mountains in the north, east, and south and densely populated Indo-Gangetic plains towards the west (which makes the region prone to heavy external influence) results in a complex aerosol environment. The blocking by mountains all around and convergence effects over the foothills of the Himalayas over north-east
India produces favourable conditions for the accumulation of both remote and local aerosols establishing a sharp regional gradient. Sitting in the foothills of the Great Himalayas, convective activities make the atmospheric constituents pile up at higher altitudes in this region ( $\mathrm{Li}$ et al. 2005), which further affects both the regional and global climate, primarily the Asian summer monsoon. Some reports have also shown that Tibetan plateau and south China are affected by pollutants transported from north-east India (Cao et al. 2010). Despite its geographical positioning and uniqueness in topography-orography, this region still remains less explored in terms of atmospheric constituents. Though much attention is given to the Tibetan Plateau and the Himalayas in recent years, the north-eastern part of India was not explored in any of the aforementioned campaigns except partly by CAIPEEX. Dibrugarh $\left(27.3^{\circ} \mathrm{N}\right.$, $\left.94.6^{\circ} \mathrm{E}, 111 \mathrm{~m} \mathrm{amsl}\right)$ is the only location across the Brahmaputra valley of north-east India, from where both short and long term measurements of aerosol properties have been made and reported in last few years by Gogoi et al. $(2009,2011)$ and Pathak et al. (2010, 2012, 2013). These studies have helped in regional characterization of atmospheric aerosols in the Indian subcontinent w.r.t its north-eastern part. It is now recognized that the aerosol abundance in the atmospheric column is high at Dibrugarh in the pre-monsoon season (March-May), followed by winter (DecemberFebruary); the lowest being in the post-monsoon season (October-November). The maximum abundance of aerosols results in the highest seasonal aerosol radiative forcing and consequent heating of the atmosphere during pre-monsoon season. On the other hand, aerosols within the PBL maximize in winter and are minimum in the monsoon season, indicating a heterogeneity between surface and column aerosol loading over this location. A statistically significant decadal increase $\left(0.0135\right.$ year $\left.^{-1}\right)$ in the column aerosol burden in terms of aerosol optical depth over Dibrugarh has been reported by Babu et al. (2013). The individual contributions of the types of aerosols, viz., continental average, marine continental average, urban/industrial and biomass burning, desert dust, and unidentified or mixed type, were found to vary seasonally with the highest contribution of urban/industrial and biomass burning in the winter (December-February). Recently, Pathak and Bhuyan (2013) have reported similar diurnal and seasonal behaviour of scattering and absorbing aerosols over Dibrugarh, which indicates that both types of aerosols originate from the same source. These studies have also shown that the aerosols/pollutants originating from different regions of India and west Asia are transported over 
the IGP through the western corridor towards the Brahmaputra valley. Aerosols from the Bay of Bengal (BoB) also find their way to the Brahmaputra basin through this corridor. This is corroborated by satellite images of intrusion of haze over the IGP and BoB to the north-east as seen in figure 1 (courtesy NASA). Therefore, to examine the spatial variability of the aerosol characteristics along the Brahmaputra valley, a land campaign was conducted by North-Eastern Space Applications Centre (NESAC) in collaboration with Dibrugarh University, from west to east during the period February 3-March 2, 2011. In this paper, we present the results of composite surface aerosol (particulate matter, PM) including black carbon (BC) measurements carried out during the campaign. The measured PM and BC concentrations have also been compared with those simulated using the Spectral Radiation-Transport Model for Aerosol Species (SPRINTARS).

\section{Study region and prevailing meteorology}

The length of the campaign trail stretched about $700 \mathrm{~km}$, from $89.97^{\circ} \mathrm{E}$ to $95.55^{\circ} \mathrm{E}$ and $26.1^{\circ} \mathrm{N}$ to $27.6^{\circ} \mathrm{N}$, starting at Dhubri $\left(26.1^{\circ} \mathrm{N}, 89.97^{\circ} \mathrm{E}\right)$ and ending at Doomdoma $\left(27.6^{\circ} \mathrm{N}, 95.55^{\circ} \mathrm{E}\right)$ (figure 2). The land campaign was conducted along the Brahmaputra valley from west to east and measurements were taken at 13 selected locations: Dhubri-DHB $\left(26.1^{\circ} \mathrm{N}, 89.97^{\circ} \mathrm{E}\right)$, Gossaigao - GSG $\left(26.45^{\circ} \mathrm{N}, 89.95^{\circ} \mathrm{E}\right)$, Bongaigaon - BNG $\left(26.52^{\circ} \mathrm{N}\right.$, $\left.90.5^{\circ} \mathrm{E}\right)$, Nalbari $-\mathrm{NBL}\left(26.47^{\circ} \mathrm{N}, 91.43^{\circ} \mathrm{E}\right)$, Guwahati GHY $\left(26.17^{\circ} \mathrm{N}, 91.75^{\circ} \mathrm{E}\right)$, Nagaon - NGN $\left(26.22^{\circ} \mathrm{N}\right.$, $\left.92.5^{\circ} \mathrm{E}\right)$, Tezpur - TZU $\left(26.7^{\circ} \mathrm{N}, 92.83^{\circ} \mathrm{E}\right)$, Bokakhat BKH $\left(26.63^{\circ} \mathrm{N}, 93.58^{\circ} \mathrm{E}\right)$, Jorhat $-\mathrm{JRH}\left(26.73^{\circ} \mathrm{N}\right.$, $\left.94.01^{\circ} \mathrm{E}\right)$, Sivasagar - SVG $\left(26.95^{\circ} \mathrm{N}, 94.63^{\circ} \mathrm{E}\right)$, Dibrugarh - DBR $\left(27.3^{\circ} \mathrm{N}, 94.6^{\circ} \mathrm{E}\right)$, Tinsukia TSK $\left(27.5^{\circ} \mathrm{N}, 95.36^{\circ} \mathrm{E}\right)$ and Doomdooma - DMD $\left(27.6^{\circ} \mathrm{N}, 95.55^{\circ} \mathrm{E}\right)$. In figure 2 , the yellow square and red triangles indicate the urban and semiurban locations respectively, while the rural locations are marked by white dots. The Brahmaputra valley is surrounded by the great Himalayan Mountains and the Tibetan plateau to the north, the hills and mountains of Yanan to the east, and the Meghalaya Plateau in the middle close to the Bangladesh-northeast India international border, open to the west side towards the IGP of mainland India. Thus, the westerly winds can play a dominant role in transporting the aerosols from west Asia, across the Indian landmass towards north-east India.

The valley is grouped into three sectors longitudinally, western sector (R1: $\left.89.97^{\circ}-91.75^{\circ} \mathrm{E}\right)$, middle sector (R2: $\left.92.5^{\circ}-94.01^{\circ} \mathrm{E}\right)$, and eastern sector (R3: $94.63^{\circ}-95.55^{\circ} \mathrm{E}$ ) based on elevation (R1: $37-$ $55 \mathrm{~m}$ amsl; R2: 57-60 $\mathrm{m}$ amsl; R3: 70-114 $\mathrm{m}$ amsl) and proximity to the external pollution source: the

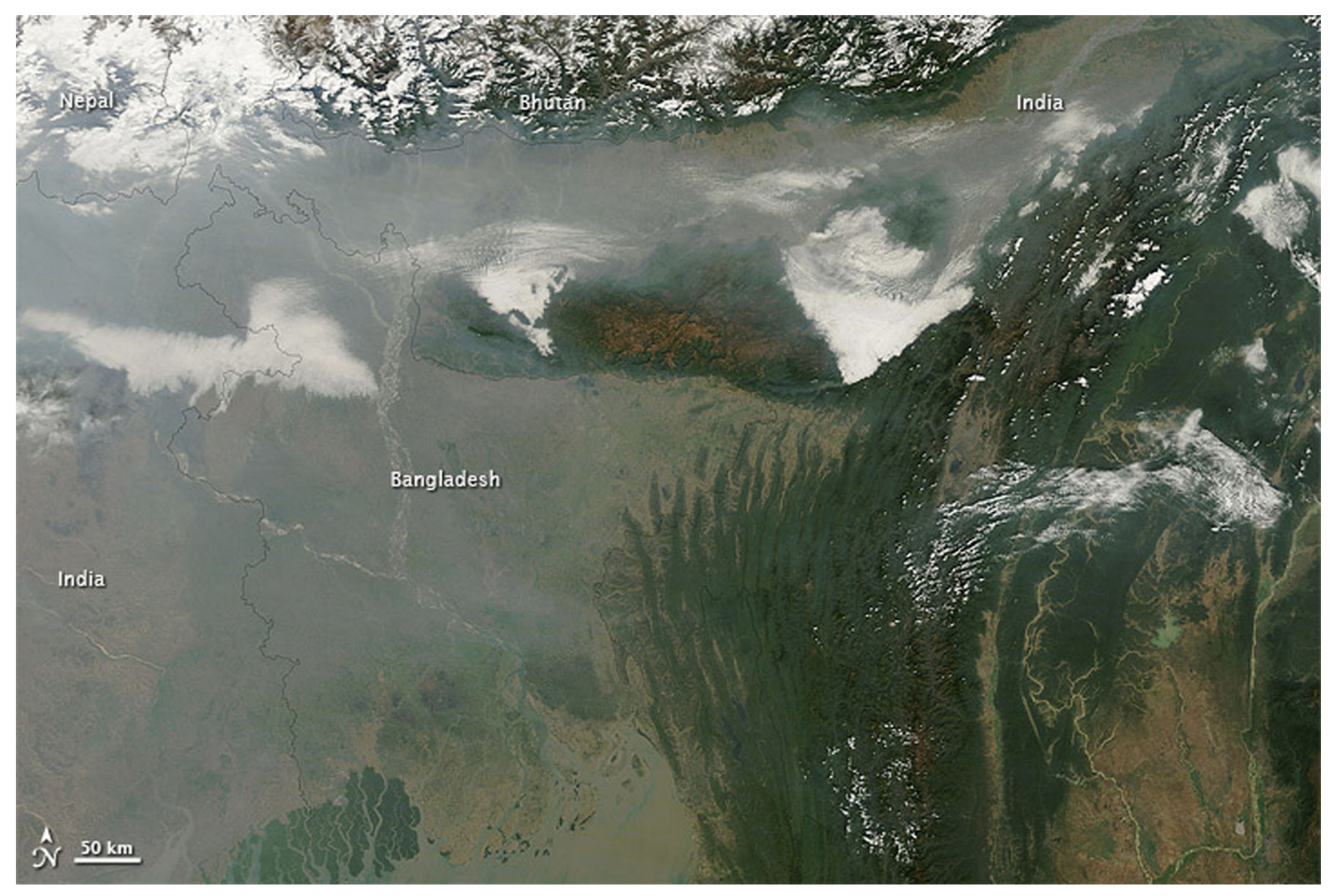

Figure 1. The intrusion of haze towards the Brahmaputra valley seen from satellites in January 2011 (courtesy NASA). 


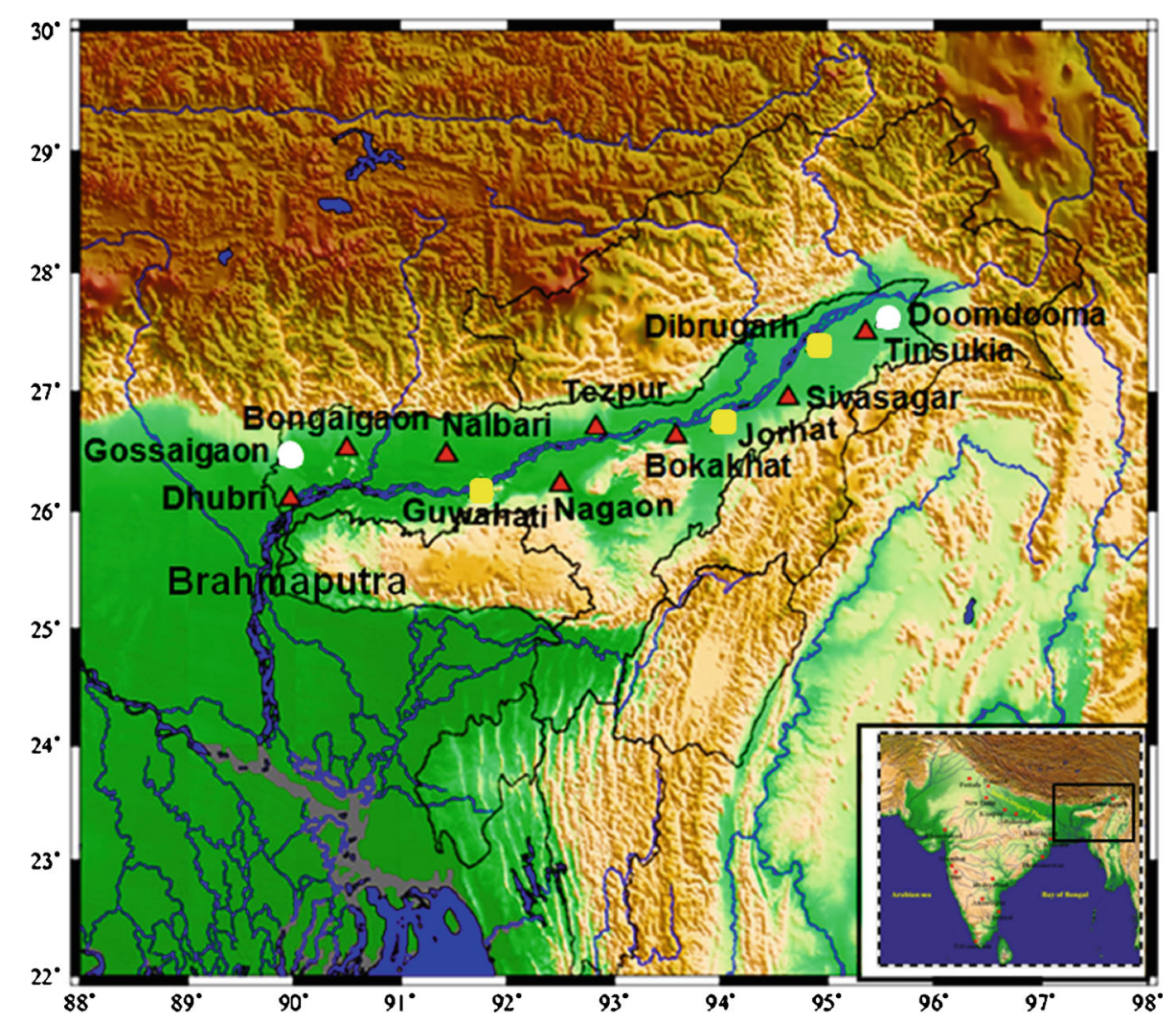

Figure 2. The location and road map of the land campaign trail across the Brahmaputra valley. The yellow square, red triangles and white dots indicate the urban, semi-urban and rural locations, respectively. Inset: Map of India showing the study region within the black square.

Indo-Gangetic plains. The link of the pollution sources like IGP and BoB, etc., to a location as far as Dibrugarh in the upper Brahmaputra valley has been observed and reported by Gogoi et al. (2011) and Pathak et al. (2012). The western sector is the gateway of westerly winds. All the measurement locations in R1 are semi-urban except the city of Guwahati (urban) and GSG (rural). Two oil refineries one in GHY and the other at BNG, and a number of coal mines in the Garo-Hills, south of R1 are the major pollution sources in this sector. The measurement locations in the middle sector are semi-urban in character and include the vast vegetation and water bodies of the Kaziranga National park, a large number of tea gardens, and one oil refinery near BKH. Though the eastern sector is mostly covered by tea gardens and large agricultural lands, JRH and DBR are the two major urban locations in Assam while the rest of the locations are semi-urban except DMD (rural). Pollution sources like burning oil and gas wells, and coal mines are scattered in these regions. The measurement sites were selectively located away from the heavy traffic or industries.

The surface meteorological parameters at the observation sites were obtained from nearby Automatic Weather Stations (AWS). Figure 3(a) shows spatial variations of the maximum and minimum temperature, maximum and minimum relative humidity $(\mathrm{RH})$, and maximum and minimum wind speed. The maximum temperature varied between $24.8^{\circ}$ and $30.9^{\circ} \mathrm{C}$, while the minimum temperature was in the range $11.1^{\circ}-18.4^{\circ} \mathrm{C}$. Difference between maximum and minimum temperature $(\Delta T)$ is less in the region R2 compared to R1 and R3. Minimum $\mathrm{RH}$ is $<50 \%$ during daytime while it reaches $99 \%$ at night. Short periodic light rainfall was recorded at Nagaon (NGN) and Tezpur (TZU) during the campaign. Surface wind is weak, north-westerly and decreases from west to east. The NCEP/NCAR reanalysis synoptic winds during the campaign period at 700 and $925 \mathrm{mb}$ are shown in figure $3(\mathrm{~b})$. The weaker winds at $925 \mathrm{mb}$ are north-westerly, while those at $700 \mathrm{mb}$ wind are strong westerly over the region.

\section{Measurements and model description}

\subsection{Instruments: Aethalometer and QCM}

The BC concentration has been obtained using an Aethalometer (Magee Scientific, Serial No. 710). The instrument measures attenuation of light beam at seven different wavelengths, viz., 370, 470, 520, 590, 660, 880, and $950 \mathrm{~nm}$, transmitted through 

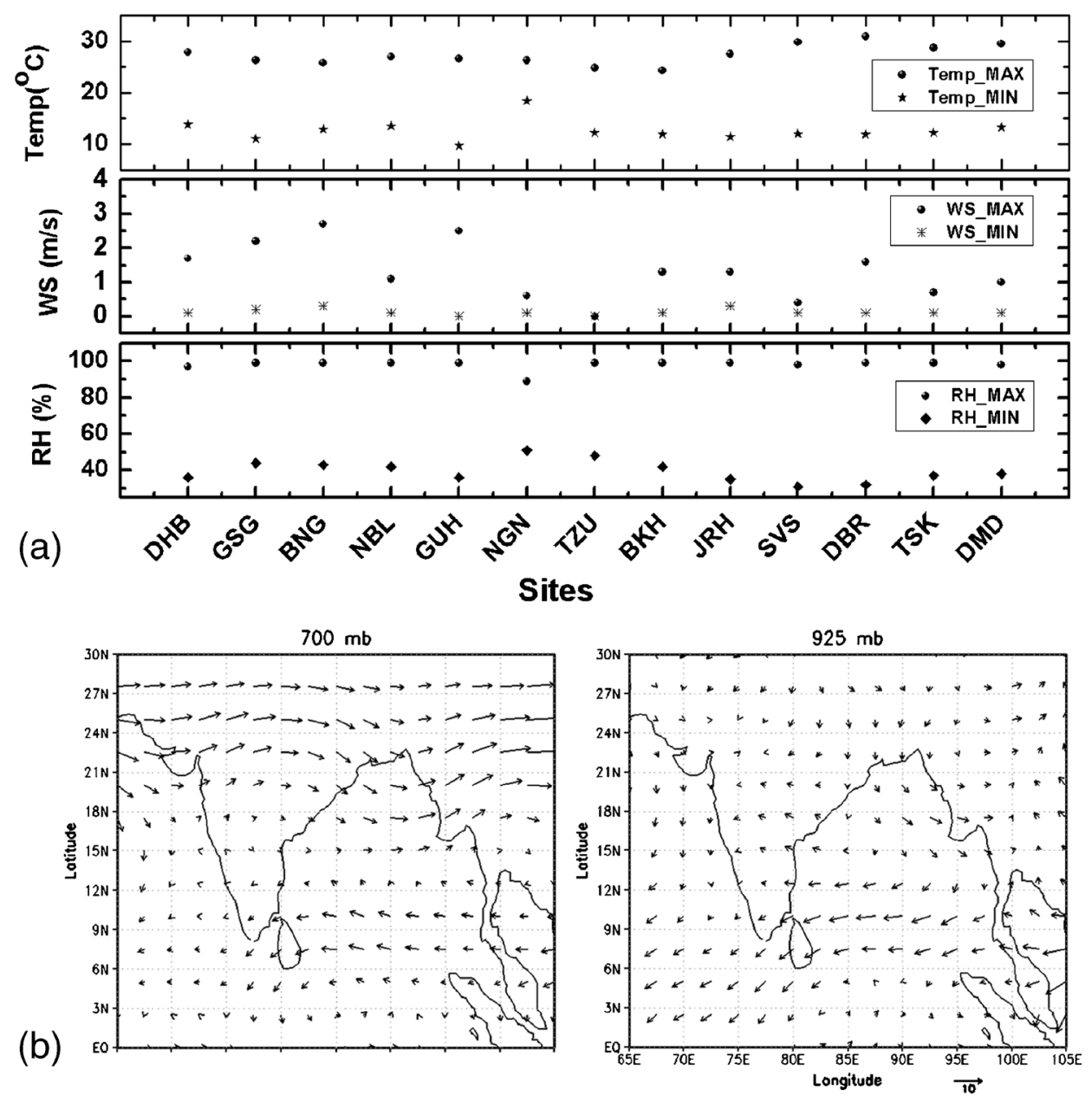

Figure 3. (a) Spatial variations of the maximum and minimum temperature, maximum and minimum relative humidity $(\mathrm{RH})$, maximum and minimum wind speed along the campaign trail; (b) the NCEP/NCAR reanalysis synoptic winds over north-east India during the campaign period at 700 and $925 \mathrm{mb}$.

the aerosols deposited continuously on a quartz fibre filter tape (Hansen et al. 1984). The difference in light transmission through the particle laden sample spot and a particle-free reference spot of the filter is used to compute the absorption coefficient, which is then converted into 'equivalent BC mass' concentration using factory set wavelength dependent calibration factors (http://mageesci. com/Aethalometer). Observation at $880 \mathrm{~nm}$ wavelength is considered standard for BC measurement as BC is the principal absorber of light at this wavelength while other aerosol components have negligible absorption. Details of the instrumentation, methodology and uncertainty are discussed elsewhere (e.g., Hansen et al. 1984; Babu et al. 2004; Nair et al. 2007). The instrument is operated round the clock at a flow rate of 3-4 LPM and with a temporal resolution of $5 \mathrm{~min}$ at all the stations. The uncertainties in the Aethalometer technique arise from the multiple scattering effects in the filter tape and the shadowing effects (e.g., Weingartner et al. 2003; Arnott et al. 2005) and the corrections for these were done following Weingartner et al. (2003) and Nair et al. (2007) as implemented by Pathak et al. (2010). Moorthy et al. (2007) have attributed an uncertainty of $20 \%$ for long term averaged $\mathrm{BC}$, but acknowledged that the systematic uncertainty might be higher.

Measurements of near surface aerosol mass and size distributions have been made using a Quartz Crystal Microbalance (QCM) Impactor (model PC-2, California Measurements Inc., USA). The QCM provides composite and size segregated mass concentration of aerosols at 10 different size ranges with $50 \%$ efficiency (cut-off diameters are at $>25$ : stage $1,12.5,6.25,3.2,1.6,0.8,0.4,0.2,0.1$, and 0.05: stage $10 \mu \mathrm{m}$ ) assuming a typical density of $2 \mathrm{~g} \mathrm{~cm}^{-3}$, for continental aerosols. In terms of aerodynamic diameter at $50 \%$ efficiency the cut-off diameters for different stages of QCM are $>35.37 \mu \mathrm{m}$ (stage 1), 17.68, 9.05, 4.53, 2.26, 1.13, 0.57, 0.28, $0.14,0.07$ (stage 10). The QCM samples air at 
a flow rate of 240 milliliters per minute. The measurements were restricted to $\mathrm{RH} \leq 75 \%$ as quartz crystals are sensitive to high relative humidity. As such, normally the observations were made at hourly intervals with sampling time duration of 5 min for each measurement from about $0700 \mathrm{hr}$ till $1900 \mathrm{hr}$ at all the sites. The measurement error for QCM remains within 15\% (Jayaraman et al. 2006; Moorthy et al. 2007).

During each measurement, the QCM provides the composite mass concentration (PM) which is the mass of aerosols for the above-mentioned size ranges in unit volume of the ambient air and the mass concentration $\left(m_{c i}\right)$ in each of its size bins $i=1$ to 10 . The composite PM concentration and $m_{c i}$ are related as $\mathrm{PM}=\sum_{i=1}^{10} m_{c i}$. The PM concentration is further classified into $\mathrm{PM}_{10}$ (aerodynamic diameter $\leq 10 \mu \mathrm{m}$ and $\mathrm{QCM}$ stages from 3 to 10 ) and $\mathrm{PM}_{2.5}$ (aerodynamic diameter $\leq 2.5 \mu \mathrm{m}$ and QCM stages from 5 to 10) following Pillai and Moorthy (2001). It may be mentioned that the aerodynamic diameters of stages 3 and 5 of the QCM do not exactly match the upper cut-off diameters of $\mathrm{PM}_{10}$ and $\mathrm{PM}_{2.5}$. The QCM size segregated mass concentrations are further used to evaluate different microphysical and optical parameters, viz., effective radius, mass mean radius, numbersize distribution, size index, and extinction coefficient following Pillai and Moorthy (2001) and Nair et al. (2008).

\subsection{SPRINTARS model}

The simulations of global three-dimensional SPRINTARS are compared with the measurements made during the campaign. The SPRINTARS is a global three-dimensional aerosol transport radiation model (Takemura et al. 2000, 2002) driven by a general circulation model (GCM), MIROC, of Atmosphere and Ocean Research Institute (AORI)/University of Tokyo, National Institute for Environmental Studies in Japan (NIES), and Japan Agency for Marine-Earth Science and Technology (JAMSTEC), and combined with the radiation scheme in the MIROC for calculating scattering and absorption of the radiation by aerosol particles. The latest version (since August 2010) of SPRINTARS is 3.84, which uses T106 horizontal resolution (approximately $1.1^{\circ} \times 1.1^{\circ}$ in latitude and longitude) and 56 layers of the vertical resolution. The model has been described in detail by Takemura et al. (2000, 2002, 2005, 2009). The emission inventories of aerosols primarily for $\mathrm{OC}$ and $\mathrm{BC}$ and its precursors, i.e., $\mathrm{SO}_{2}$ used in the SPRINTARS model simulations are widely used in the AeroCom (AC) project (Diehl et al. 2012). The anthropogenic primary organic aerosol and BC emissions are based on Bond et al. (2004). The SPRINTARS model simulations have been widely used to compare with ground-based measurements by Goto et al. (2011a, b), Pathak et al. (2013), etc., over the Indian subcontinent.

\section{Results and discussion}

\subsection{Spatial variability of BC aerosol characteristics}

Spatial heterogeneity in the distribution of surface aerosol concentration including $\mathrm{BC}$ has been observed along the Brahmaputra valley. The measured $\mathrm{BC}$ concentration at all the locations was averaged for the two days of observations except at NGN (observation was available for one day) and the spatio-temporal variability is presented in figure $4(\mathrm{a}$ and $\mathrm{b})$. The diurnal $\mathrm{BC}$ concentration shows a primary peak around 1900-2200 hr (local time) and a less prominent secondary maximum in the morning between 0600 and $0900 \mathrm{hr}$ (figure 4a). The diurnal peak slightly shifts with location. Minimum BC was observed in the daytime between 1000 and $1600 \mathrm{hr}$. Identical diurnal variation at all the locations suggests that $\mathrm{BC}$ concentration is mainly governed by the diurnal evolution of the atmospheric boundary layer $(\mathrm{ABL})$, which remains low during morning hours, then gradually deepens to its peak by the noon time and starts decreasing in the evening (Krishnan and Kunhikrishnan 2004). Later in the evening and throughout the night, on the other hand, the radiative cooling of the ground surface results in the suppression or weakening of turbulent mixing and consequently in the collapse of the ABL depth. This results in the confinement of aerosols and a gradual increase in its concentration after sunset. After reaching a peak level few hours before midnight, $\mathrm{BC}$ concentration decreases gradually due to reduction in anthropogenic activities. Gradual increase in BC concentrations from around dusk is due to increased production of $\mathrm{BC}$ aerosols as a result of increased household activities and gradual formation of a surface-based inversion opposing vertical mixing in the atmosphere (Ganguly et al. 2006). The small secondary peak observed in winter after daybreak between 0600 and $0900 \mathrm{hr}$ is associated with household as well as other open air burning activities. Pathak et al. $(2010,2013)$ have reported similar variability in BC concentration from Dibrugarh. It is seen from figure 4(b) that daily mean BC mass concentration varies between higher value of $\sim 25 \mu \mathrm{gm}^{-3}$ at NBL and lower value of $\sim 7 \mu \mathrm{gm}^{-3}$ at TZU. The R1 locations are rich in $\mathrm{BC}$ concentration near the surface $\left(18.4 \pm 3.9 \mathrm{\mu gm}^{-3}\right)$ as compared to the other two sectors with almost similar concentra-

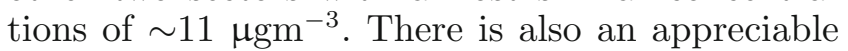



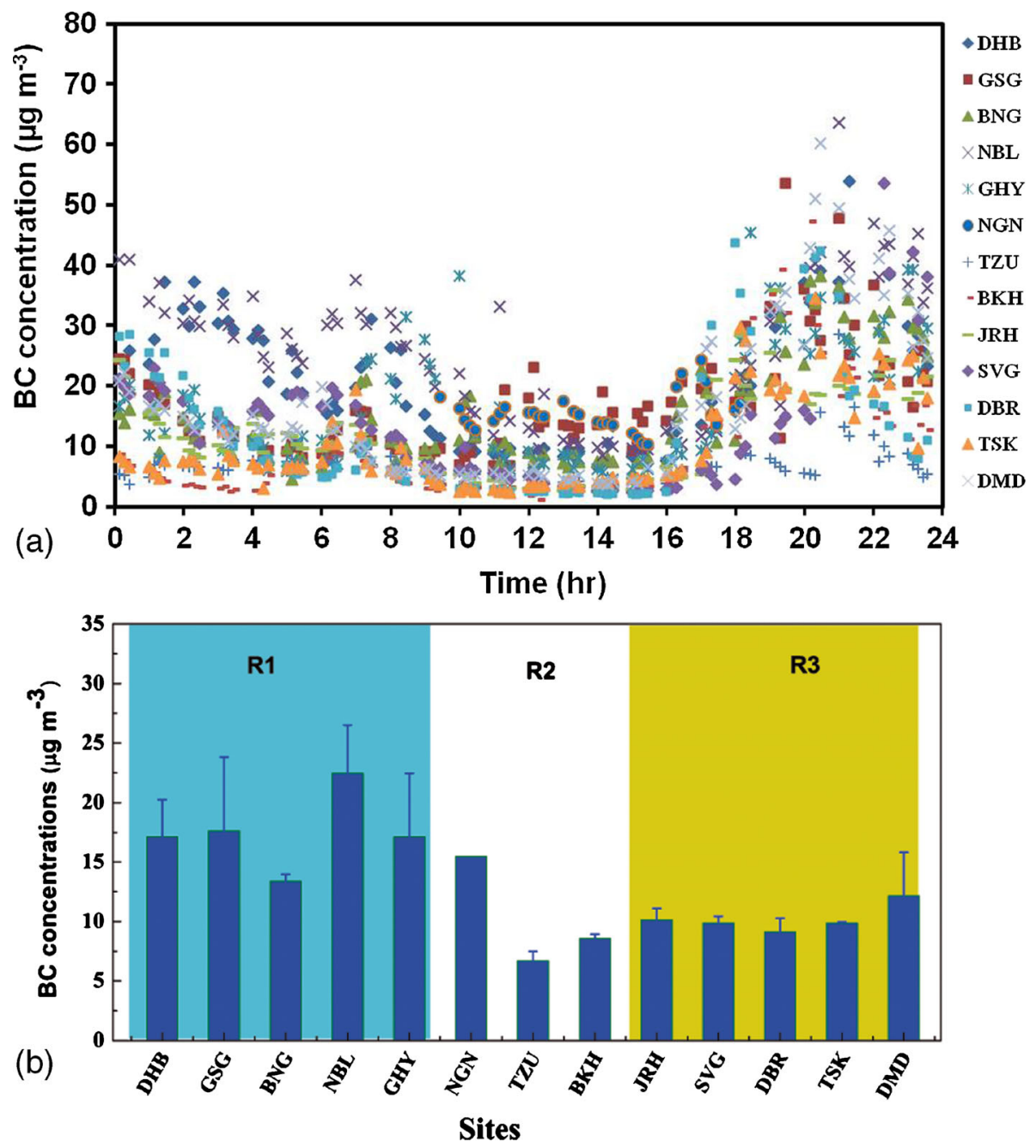

Figure 4. (a) Diurnal and spatial variation and (b) sitewise distribution of black carbon along the campaign trail.

day-to-day variability in $\mathrm{BC}$ concentration particularly at the western locations and at DMD in the eastern sector. This may be attributed partly to the proximity of these locations to coal mines or coal dumps. A decreasing trend in $\mathrm{BC}$ concentration is observed from west to east. This spatial variability in $\mathrm{BC}$ concentration may be described in relation to the transported pollutants from western locations of India over the IGP. This is evident from the concentration weighted trajectory analysis (Ward 1963; Gogoi et al. 2011 and references therein) carried out at $500 \mathrm{~m}$ AGL for BC concentration (figure 5). Trajectories from $\mathrm{BoB}$ are present at NGN and TZU, which might have carried the moisture necessary for the drizzle recorded at these two locations. Trans-Himalayan trajectories are present at eastern locations. Thus, the western locations in $\mathrm{R} 1$ region are affected more by the pollutants transported from IGP compared to other two locations due to the gradual reduction of pollutants with distance from the source. The contributions from the coal mines and coal loading railway yards might be partially responsible for the observed high BC concentration in R1. Pathak et al. (2010), for the period June 2008-May 2009, have reported a significant level of $\mathrm{BC}$ concentration over Dibrugarh; more than many urban locations of the Indian subcontinent except Kanpur. However, BC over the years (2008-2012) indicates a decreasing trend over Dibrugarh (Pathak et al. 2013).

\subsection{Surface aerosol's contribution to extinction of radiation and loading: spatial variability}

The contribution of aerosols to the extinction of solar radiation is evaluated in terms of the extinction coefficient $\left(\beta_{\text {ext }}\right)$. It is estimated from the number size distribution $(d n(r) / d r)$ of surface aerosols following the equation

$$
\beta_{\mathrm{ext}}=\int_{r_{1}}^{r_{2}} \pi r^{2} Q_{\mathrm{ext}}(m, r, \lambda) \frac{d n(r)}{d r} d r,
$$




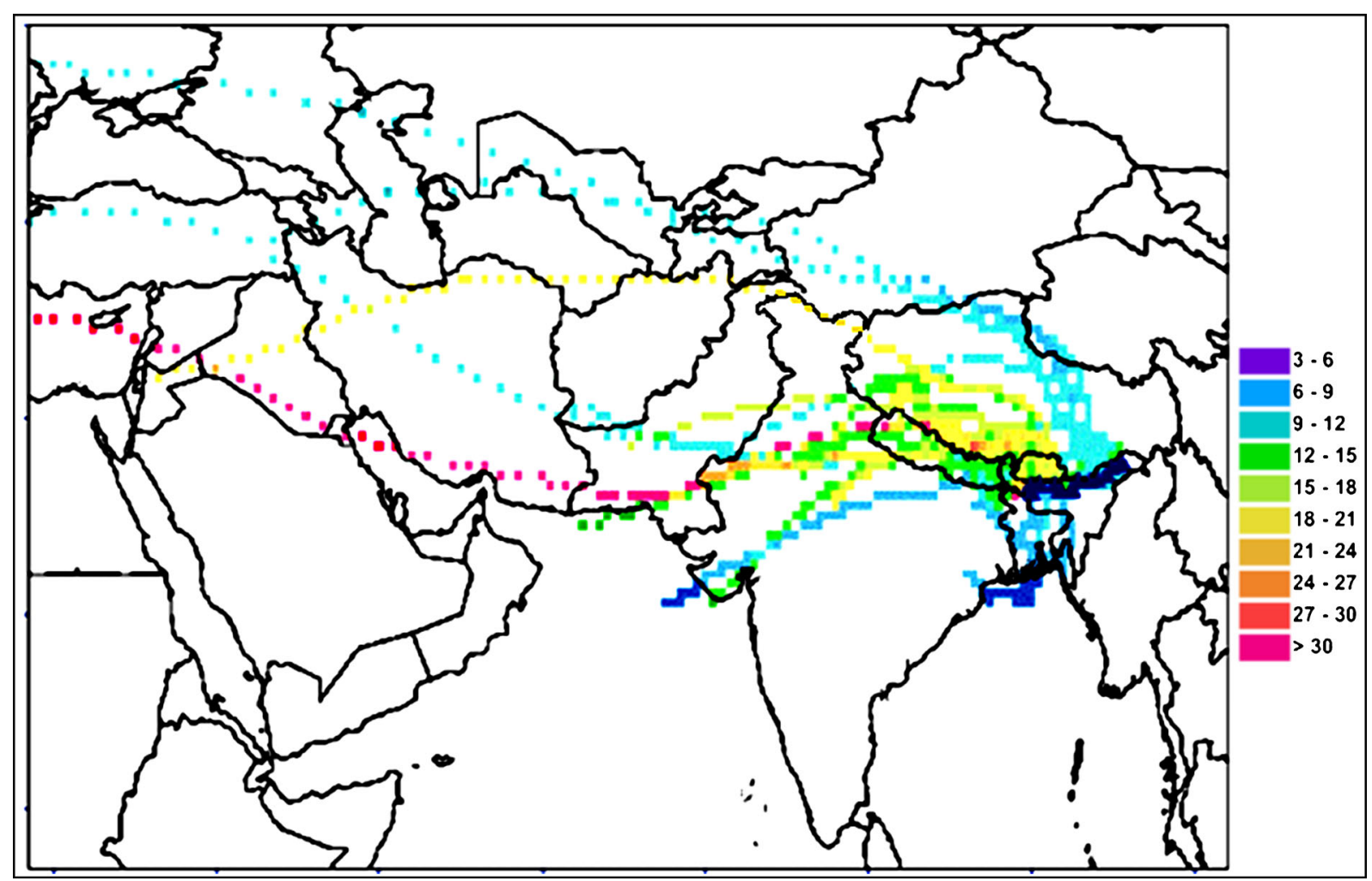

Figure 5. Concentration weighted trajectory tracks at $500 \mathrm{~m}$ AGL to each location of the campaign trail.

where $Q_{\text {ext }}$ is the Mie extinction efficiency parameter, which is a function of particle size $(r)$ in relation to the wavelength $(\lambda)$ of radiation and its complex refractive index $(m)$. $\beta_{\text {ext }}$ is determined at wavelength $500 \mathrm{~nm}$ by estimating the Mie extinction parameters for the particle size range covered in the QCM (except first stage). As the BC fractions measured along the campaign trail exhibit significant spatial variability, the refractive indices $(m)$ for the composite aerosols at each location were determined. For determining $m$, external mixture of four components: organics, BC, sulfate, and dust were considered following Pathak et al. (2010). They have used a mixture of water soluble (organics), insoluble, mineral (dust), BC and sulfate for estimation of optical parameters for radiative forcing calculations over DBR. As the terrain along the Brahmaputra valley is nearly uniform the combination (and fractions) of organics, sulfate and dust was assumed constant and BC was varied for each location. The refractive indices for organics, sulfate, dust and $\mathrm{BC}$ at $500 \mathrm{~nm}$ were adopted from Lubin et al. (2002) and the resultant refractive index for the external mixture was estimated as presented in table 1 . The number size distributions used for the estimation of $\beta_{\text {ext }}$ for each location were estimated from the QCM measured mass-size distribution (Pathak et al. 2013 and references therein) and discussed later.
The $\beta_{\text {ext }}$ so obtained is shown in figure (6, top pannel) and varies from a minimum of $\sim 0.02$ at DMD of R3 and a maximum of 0.25 at NBL of R1. Substantial $\beta_{\text {ext }}$ is observed at BNG of R1 leading to highest regional average $\beta_{\text {ext }}$ at R1 (0.14). The regional average $\beta_{\text {ext }}$ is lowest at R3 (0.07). Thus it is clear that the near surface aerosols in the western locations contribute more to the extinction of solar radiation compared to other regions of the Brahmaputra valley. Pathak et al. (2013) have reported $\beta_{\text {ext }} \sim 0.07-0.1$ in winter (December-February) over Dibrugarh.

The particulate matter (PM) concentrations, viz., $\mathrm{PM}, \mathrm{PM}_{10}$ and $\mathrm{PM}_{2.5}$ are presented in figure 6 (bottom pannel). The highest PM concentrations (PM, $\mathrm{PM}_{10}, \mathrm{PM}_{2.5}$ ) are observed at sites located in $\mathrm{R} 1$ with maximum regional average values of 40.9 $\pm 12.2,36.7 \pm 11.9,34.4 \pm 12.0{\mu \mathrm{gm}^{-3}}$, respectively. Despite the light rain at two sites NGN and TZU, appreciable regional average PM concentrations in R2 $(38.8 \pm 12.1,35.4 \pm 11.5,33.1$

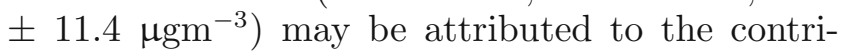
bution from the site BKH. Most of the sites in R3 show low PM concentrations which lead to a regional average value of $35.6 \pm 11.2,31.2 \pm 11.3$, $28.4 \pm 11.6 \mathrm{\mu gm}^{-3}$, respectively for $\mathrm{PM}, \mathrm{PM}_{10}$, $\mathrm{PM}_{2.5}$. There are several reasons for this spatial inhomogeneity: firstly, R1 locations are closer to $\mathrm{BoB}$; the remnants of the winter haze from IGP 
Table 1. Spatial variation of refractive index for varying $B C$ fraction, calculated following Lubin et al. (2002).

\begin{tabular}{lllc}
\hline Site & \multicolumn{1}{c}{$\mathrm{F}_{B C}$} & Real & Imaginary \\
\hline Dhubri & 0.283772763 & 1.847 & 0.1227 \\
Gossaigaon & 0.361711722 & 2.020 & 0.1590 \\
Bongaigaon & 0.184910562 & 1.640 & 0.0790 \\
Nalbari & 0.28586952 & 1.859 & 0.1241 \\
Guwahati & 0.318702207 & 1.923 & 0.1387 \\
Nagaon & 0.315428723 & 1.913 & 0.1370 \\
Tezpur & 0.117718398 & 1.514 & 0.0509 \\
Bokakhat & 0.065478261 & 1.502 & 0.0313 \\
Jorhat & 0.080241542 & 1.506 & 0.0371 \\
Sivasagar & 0.074313877 & 1.504 & 0.0348 \\
Dibrugarh & 0.113534768 & 1.513 & 0.0494 \\
Tinsukia & 0.127079905 & 1.531 & 0.0548 \\
Doom Doma & 0.158568135 & 1.595 & 0.0681 \\
\hline
\end{tabular}

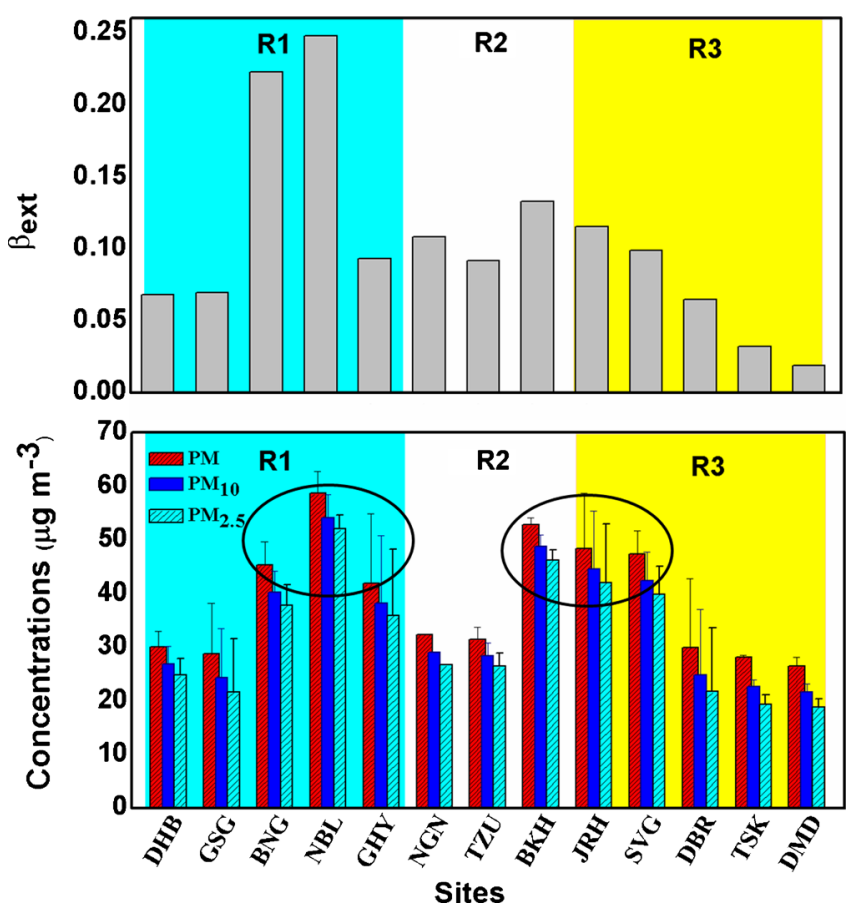

Figure 6. Spatial distribution of (a) near surface extinction coefficient and (b) particulate matter concentrations, viz., $\mathrm{PM}, \mathrm{PM}_{10}$ and $\mathrm{PM}_{2.5}$ along the campaign trail. Black circles in (b) indicate PM hotspot clusters.

heading towards BoB also enter NE India through the corridor and result in higher aerosol loading at the western locations (R1). Moreover, high population density in R1 and R2 leads to higher anthropogenic aerosols over those regions. The population density in most of the locations in the region R3 is lower compared to that in R1 and R2. The effect of the winter haze is expected to be comparatively lower in this eastern part of the campaign trail.
Despite its rural character, the highest mass concentration has been observed at NBL. Proximity to the city of Guwahati may have added the aerosol concentration there together with the transportation from distant places. Similarly, at $\mathrm{BKH}$ also, the nearby cement factory and the oil refinery may have contributed to the observed high PM concentrations. Two clusters of hotspots of PMs are present (black circle in figure 6, bottom pannel) in the campaign trail. The sites BNG and NBL, which are within the PM hotspot in R1 also exhibit highest $\beta_{\text {ext }}$ values (figure 6 , top pannel), whereas $\beta_{\text {ext }}$ in the other PM hotspot are lower. The high $\beta_{\text {ext }}$ in the PM hotspots of $\mathrm{R} 1$ may be attributed to the effect of higher $\mathrm{BC}$ fraction on refractive index of composite aerosols.

It is found that $\mathrm{PM}_{2.5}$ aerosols contribute more to the total aerosol mass at all the sites, which is one of the characteristic features of the continental aerosols. The percentage contribution of $\mathrm{PM}_{2.5}$ to $\mathrm{PM}$ varies between 80 and $85 \%$ at all the three regions, while $\mathrm{PM}_{10-2.5}\left(\mathrm{PM}_{10}-\mathrm{PM}_{2.5}\right)$ contribution is least along the Brahmaputra valley. A similar result has been reported by Pathak et al. (2010, 2013) at Dibrugarh. The lower value of coarse mode aerosol mass may be due to lower wind speed, which is not very efficient in lifting coarse mode dust from the surface. Again, due to low flow rate (240 milliliters per minute) of the instrument, the particles at a distance may not be fully drawn into the system and this, along with the length of the inlet pipe $(1 \mathrm{~m})$ used, may present a difficulty in detection of coarse mode aerosols over the sites (Pathak et al. 2010). Fine aerosols, owing to their longer lifetime, are amenable to long range transportation. Such transportations to the present study locations have been reported by Gogoi et al. (2009, 2011). In addition, during the post-harvesting season, burning of residual agricultural crop in the nearby places contributes to the production of fine aerosols and precursor gases, which in turn produce secondary aerosols, mostly in accumulation mode. The present measurement locations being continental, aerosols over these sites, both local and transported, are richer in accumulation regime $\left(\mathrm{PM}_{2.5}\right)$. Also, most of the fine mode aerosols (soot, sulfate, etc.) are associated with anthropogenic sources (fossil fuel or biomass/biofuel burning); their concentration increases at times when local generation of aerosols is prominent.

Winter maximum concentration of PM has been reported from Dibrugarh, one of the locations in R3 by Pathak et al. $(2010,2013)$ and also from other parts of India, e.g., over Ahmedabad by Ganguly et al. (2006) for the period 20022004, over coastal region Trivandrum by Moorthy et al. (2007). During ISRO-GBP land campaign-I, 
Moorthyet al. (2005) observed that over most of the coastal regions $\mathrm{PM}$ varies from 50 to $80 \mu \mathrm{g} \mathrm{m} \mathrm{m}^{-3}$ whereas it was $<40 \mu \mathrm{g} \mathrm{m}^{-3}$ over most of the inland regions in the south and west, dropping at times to as low as $\sim 20 \mu \mathrm{g} \mathrm{m}^{-3}$. They identified hotspots of aerosol mass concentration $\left(>60 \mu \mathrm{g} \mathrm{m}^{-3}\right)$ around coastal, industrialized, and urban areas which include Goa, Chennai, Trivandrum, Vijayawada, Visakhapatnam, Cuttack, and Raipur. They have also observed that accumulation-mode aerosols contributed more than $60 \%$ of the total aerosol mass concentration at coastal locations, while it is seen to be about $40 \%$ over the interior semiarid continental regions. During the second land campaign (Land campaign II) of ISRO-GBP conducted over Indo-Gangetic belt in the north Indian corridor in December 2004, very high concentration of aerosols has been observed. The PM concentration was in the range $260-300 \mu \mathrm{g} \mathrm{m} \mathrm{m}^{-3}$ over the three stations, namely Kharagpur, Allahabad, and Kanpur out of eight measurement stations (ARFI Report 2007-2008). Higher contribution of fine mode aerosols to PM was also observed in all the three stations with $\sim 90 \%$ over Allahabad, $77 \%$ over Kharagpur, and $74 \%$ over Kanpur. Thus the scenario of $\mathrm{PM}_{2.5}$ aerosol abundance over Brahmaputra valley is in close resemblance with IGP. Hence, the premise that during winter fine aerosols from IGP are transported towards present study location supports the observation.

The number size distribution over each region monotonically decreases towards the larger size particles (figure 7a). This suggests the possibility of occurrence of particles smaller than $0.07 \mu \mathrm{m}$ near the surface at each of the region. Due to the limitation in size resolution of the QCM, the present values of $d n(r) / d r$ does not provide information regarding ultrafine particles and hence there may be a possibility of such particles being below aerodynamic diameter $\sim 0.07 \mu \mathrm{m}$ (Nair et al. 2008; Pathak et al. 2013). It may be noted that QCM does not respond to moderate changes in $d n(r) / d r$ due to the coarser size resolution. Lower value of effective radius $\left(R_{\text {eff }}\right)$ varying between 0.08 and $0.14 \mu \mathrm{m}$ also indicates abundance of fine aerosols over the region. The size index lying in the range $\sim 4-4.3$ suggests homogeneity in particle size distribution and this value is the representative for aerosols of continental origin (figure $7 b$ ).

\subsection{Absorption coefficient and absorption Angström exponent}

The absorption coefficient, which is a measure of the amount of particulate absorption in the atmosphere, is an essential parameter for radiative forcing calculations (Bond et al. 2013). Figure 8 shows the (a) absorption coefficient at $520 \mathrm{~nm}$ and (b) absorption Ångström exponent $\left(\alpha_{\text {abs }}\right)$, calculated from the spectral dependence of absorption coefficient. Absorption coefficient at $520 \mathrm{~nm}$ shows similar spatial variability as $\mathrm{BC}$ concentration. The $\alpha_{\text {abs }}(\geq 2)$ is an indication of higher $\mathrm{OC} / \mathrm{BC}$ ratio, while low $\alpha_{\text {abs }} \leq 1$ represents high $\mathrm{BC} / \mathrm{OC}$ ratio. $\alpha_{\text {abs }}$ along the Brahmaputra valley remains around 1.25 and indicates the presence of $\mathrm{BC}$ aerosols originating both from biomass and fossil fuel burning. The open coal mines in the Garo-Hills south of the region $\mathrm{R} 1$ and oil fields in $\mathrm{R} 3$ are the local sources of $\mathrm{BC}$ in the atmosphere. These, together with the industrial pollutants from IGP, dominate the $\mathrm{BC}$ concentration which leads to observed $\alpha_{\text {abs }}<1.5$.

\subsection{Measurement versus model simulation}

The difference between the measured and SPRINTARS simulated PM and BC concentrations $\left(\delta \mathrm{m}\left(\mathrm{PM}_{10}, \mathrm{PM}_{2.5}, \mathrm{BC}\right)=\right.$ measured-model $)$ for each day of observation (total 25 days) at each location is shown in figure 9. The model mostly underestimates the measured $\mathrm{PM}_{10}$ and $\mathrm{PM}_{2.5}$ at $\mathrm{R} 3$ and $\mathrm{R} 2$ while at $\mathrm{R} 1$ the model overestimates at most of the sites. As seen from the figure, the variation of $\mathrm{BC}$ within the campaign trail has not been captured adequately by the model leading to higher underestimation in western locations as compared to the middle and eastern locations. This may be associated with the large uncertainty in the $\mathrm{BC}$ emission inventory. Emissions from biomass burning, which form a major portion of atmospheric aerosols in India during the period February-April (Badarinath and Kharol 2008) are not properly accounted for in the emission inventories (Goto et al. 2011b and references therein). Particularly, the undetected local emissions from burning of agricultural residues and anthropogenic indoor and outdoor burnings are difficult to quantify and not accounted for in the model. Goto et al. (2011b) have reported the model underestimation in the areas where observed $\mathrm{BC}$ concentration values exceed $15 \mu \mathrm{g} \mathrm{m} \mathrm{m}^{-3}$. The coarse spatial resolution of the model $\left(2.8^{\circ} \times 2.8^{\circ}\right.$ in latitude and longitude) may add to the uncertainty of the model simulation. The observed discrepancies between model simulation and observation may also be attributed to boundary layer dynamics not being given adequate consideration in the model. During winter the boundary layer is very thin and enhanced entrapment of pollutants produced near the surface increases. The evolution of summertime boundary layer is more consistent and perhaps well represented in global 

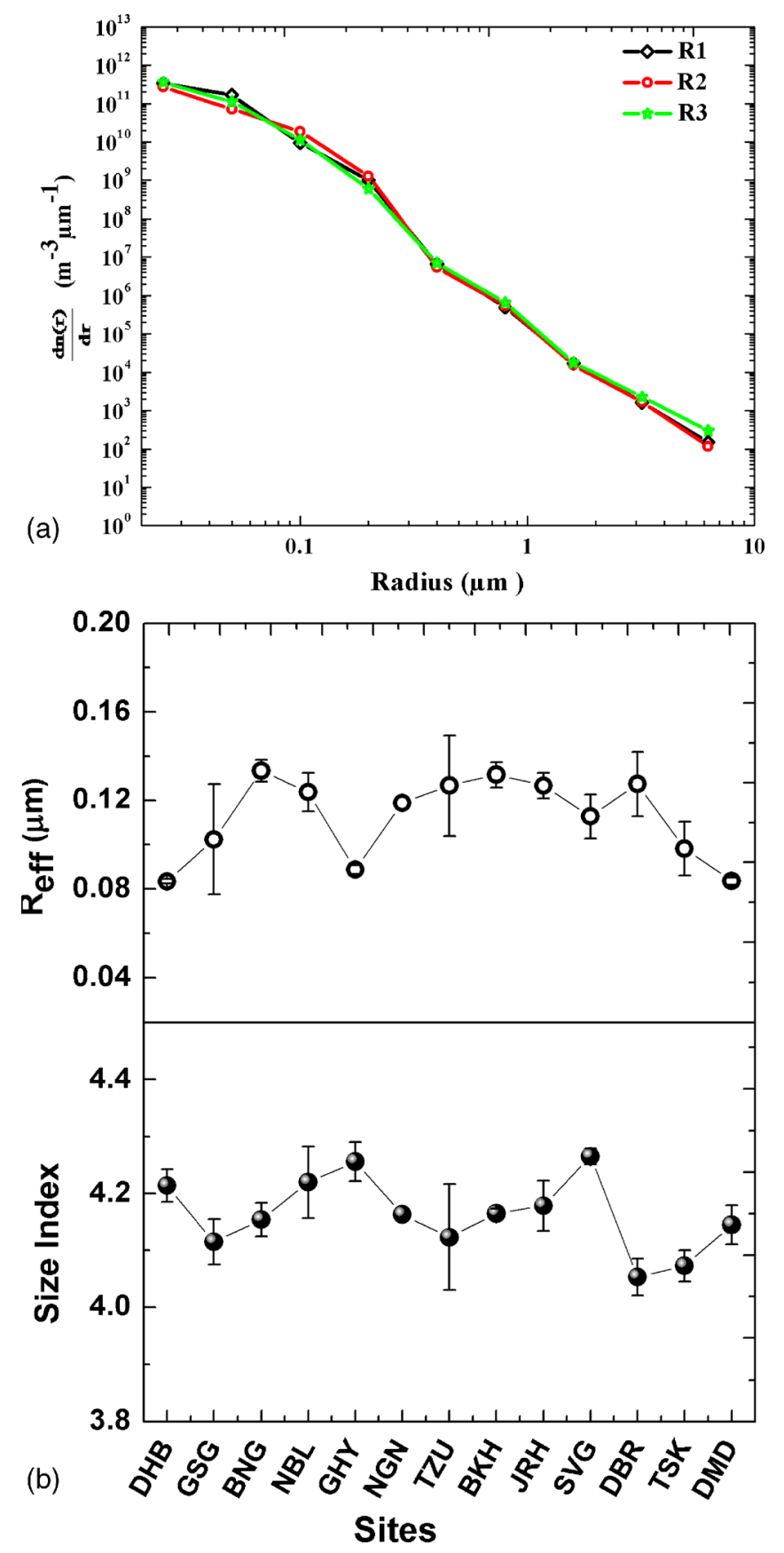

Figure 7. (a) The regional average number size distribution and (b) spatial distribution of effective radius and size index along the campaign trail.

models. Unlike many other locations of the Indian subcontinent, the diurnal $\mathrm{BC}$ concentration peaks during pre-midnight hours along the Brahmaputra valley. It has been reported earlier that $\mathrm{BC}$ concentration over north-east India is comparable to those at polluted cities like Kanpur and Delhi (Pathak et al. 2010) which is another reason for the underestimation by the model. Pathak et al. (2013) have shown SPRINTARS overestimation in $\mathrm{PM}_{10}$ and $\mathrm{PM}_{2.5}$ and underestimation in $\mathrm{BC}$ for the period 2007-2012 over Dibrugarh and

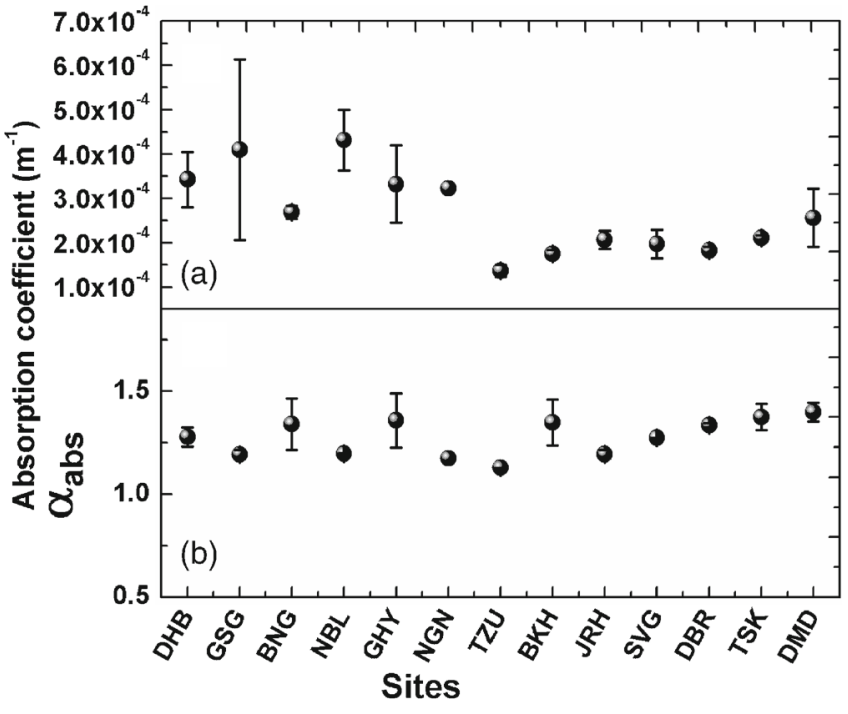

Figure 8. Variation of (a) absorption coefficient at $520 \mathrm{~nm}$ and (b) absorption Ångström exponent $\left(\alpha_{\text {abs }}\right)$ along the campaign trail.

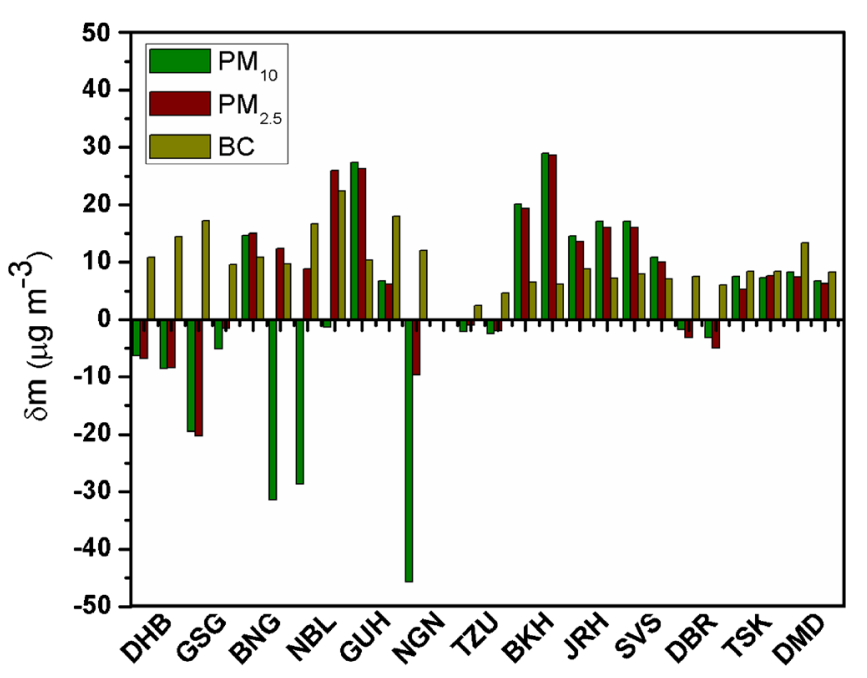

Figure 9. Difference between measured and simulated $(\delta \mathrm{m})$ $\mathrm{PM}_{10}, \mathrm{PM}_{2.5}$ and $\mathrm{BC}$ concentrations for each measurement day at the locations along the campaign trail.

have attributed the same to the lack of emission inventories from the region.

\section{Conclusions}

An aerosol land campaign was conducted from February 3 to March 2, 2011 along the Brahmaputra valley from west to east. The salient points of the campaign results may be summarized as follows:

- Prominent spatial heterogeneity in aerosol characteristics has been observed across the Brahmaputra valley. There is an east-west asymmetry in PM and BC across the valley. Eastern locations 
are less polluted compared to the western and middle Assam locations.

- Surface aerosols are dominated by smaller size particles (i.e., $\mathrm{PM}_{2.5}$ ) throughout the campaign trail.

- Two hotspot clusters of aerosols $\left(>40 \mu \mathrm{g} \mathrm{m} \mathrm{m}^{-3}\right)$ have been identified.

- Northwesterly surface wind direction and trajectory analysis show contribution of aerosols from western India across IGP, primarily in the western locations.

- SPRINTARS underestimates the $\mathrm{PM}_{10}$ and $\mathrm{PM}_{2.5}$ at most of the locations of $\mathrm{R} 2$ and $\mathrm{R} 3$ while at $\mathrm{R} 1$ the model overestimates at most of the sites.

- The model estimated BC concentration is lower than measured values all along the campaign trail. This suggests that the variation of $\mathrm{BC}$ within the campaign trail has not been captured adequately by the model, primarily in the western locations where $\mathrm{BC}$ concentration is high, leading to higher disagreement there, as compared to the middle and eastern locations.

\section{Acknowledgements}

The campaign was carried out with partial support under ISRO-GBP ARFI project. B Pathak is thankful to DST for providing financial assistance in the form of young scientist fellowship. The authors are thankful to the anonymous referees for their helpful suggestions towards improvement of the manuscript.

\section{References}

Arnott W P, Hamasha K, Moosmuller H, Sheridan P J and Ogren J A 2005 Towards aerosol light-absorption measurements with a 7-wavelength Aethalometer: Evaluation with a photoacoustic instrument and 3-wavelength Nephelometer; Aerosol. Sci. Technol. 39(1) 17-29, doi: 10.1080/027868290901972.

Babu S S, Manoj M R, Krishna Moorthy K, Gogoi Mukunda M, Nair Vijayakumar S, Kompalli Sobhan Kumar, Satheesh S K, Niranjan K, Ramagopal K, Bhuyan P K and Singh Darshan 2013 Trends in aerosol optical depth over Indian region: Potential causes and impact indicators; J. Geophys. Res. 118 1-13, doi: 10.1002/2013JD020507.

Babu S S, Moorthy K K and Satheesh S K 2004 Aerosol black carbon over Arabian Sea during intermonsoon season and summer monsoon season; Geophys. Res. Lett. 31 L06104, doi: 10.1029/2003GL018716.

Badarinath K V S and Kharol S K 2008 Studies on aerosol properties during ICARB 2006 Campaign period at Hyderabad, India using ground based measurements and satellite data; J. Earth Syst. Sci. 117(S1) 413-420.

Bond T C, Streets D G, Yarber K F, Nelson S M, Woo J-H and Klimont Z 2004 A technology-based global inventory of black and organic carbon emissions from combustion; J. Geophys. Res. 109 D14203, doi: 10.1029/2003JD003697.

Bond et al. 2013 Bounding the role of black carbon in the climate system: A scientific assessment; J. Geophys. Res. 118 5380-5552, doi: 10.1002/jgrd.50171.

Cao J, Tie X, Xi B and Zhao Z 2010 Measuring and modeling black carbon (BC) contamination in the $\mathrm{SE}$ Tibetan Plateau; J. Atmos. Chem. 67 45-60, doi: 10.1007/s10874-011-9202-5.

Diehl T, Heil A, Chin M, Pan X, Streets D, Schlz M and Kinne S 2012 Anthropogenic, biomass burning, and volcanic emissions of black carbon, organic carbon, and $\mathrm{SO}_{2}$ from 1980 to 2010 for hindcast model experiments; Atmos. Chem. Phys. Discuss. 12 24,895-24,954, doi: 10.5194/acpd-12-24895-2012.

Ganguly D, Jayaraman A and Gadhavi H 2006 Physical and optical properties of aerosols over an urban location in western India: Seasonal variabilities; J. Geophys. Res. 111 D24206, doi: 10.1029/2006JD007392.93.

Gogoi M M, Moorthy K K, Babu S S and Bhuyan P K 2009 Climatology of columnar aerosol properties and the influence of synoptic conditions: First-time results from the northeastern region of India; J. Geophys. Res. 114 D08202, doi: 10.1029/2008JD010765.

Gogoi M M, Pathak B, Moorthy K K, Bhuyan P K, Babu S S, Bhuyan K and Kalita G 2011 Multi-year investigations of near surface and columnar aerosols over Dibrugarh, north-eastern location of India: Heterogeneity in source impacts; Atmos. Env. 45 1714-1724, doi: 10.1016/j.atmos env.2010.12.056.

Goto D, Badarinath K V S, Takemura T and Nakajima T 2011a Simulation of aerosol optical properties over a tropical urban site in India using a global model and its comparison with ground measurements; Ann. Geophys. 29 955-963.

Goto D, Takemura T, Nakajima T and Badarinath K V S 2011b Global aerosol model-derived black carbon concentration and single scattering albedo over Indian region and its comparison with ground observations; Atmos. Environ. 45 3277-3285.

Hansen A D A, Rosen H and Novakov T 1984 The Aethalometer - an instrument for the real-time measurement of optical absorption by aerosol particles; Sci. Total Environ. 36 191-196.

Jayaraman A, Gadhavi H, Ganguly D, Misra A, Ramachandran S and Rajesh T 2006 Spatial variation in aerosol characteristics over central India observed during the February 2004 road campaign experiment; Atmos. Env. 40 6504-6515.

Kaufman Y J, Tanre' D, Dubovik O, Karnieli A and Remer L A 2001 Absorption of sunlight by dust as inferred from satellite and ground-based remote sensing; Geophys. Res. Lett. 28 1479-1482.

Krishnan P and Kunhikrishnan P K 2004 Temporal variations of ventilation coefficient at a tropical Indian station using UHF wind profiler; Curr. Sci. 86 447-451.

Li Q et al. 2005 Convective outflow of south Asian pollution: A global CTM simulation compared with EOS MLS observations; Geophys. Res. Lett. 32 L14826, doi: 10.1029/2005GL022762.

Lubin D, Satheesh S K, McFarquar G and Heymsfield A J 2002 Longwave radiative forcing of Indian Ocean tropospheric aerosol; J. Geophys. Res. 107(D19) 8004, doi: 10.1029/2001JD001183.

Moorthy K K, Babu S S and Satheesh S K 2005 Aerosol characteristics and radiative impacts over the Arabian Sea during inter-monsoon season: Results from the ARMEX field campaign; J. Atmos. Sci. 62 192-206, doi: 10.1175/JAS-3378.1. 
Moorthy K K, Babu S S and Satheesh S K 2007 Temporal heterogeneity in aerosol characteristics and the resulting radiative impact at a tropical coastal station - Part 1: Microphysical and optical properties; Ann. Geophys. 25 2293-2308.

Moorthy K K, Satheesh S K, Suresh Babu S and Dutt C B S 2008 Integrated campaign for aerosols, gases and radiation budget (ICARB): An overview; J. Earth Syst. Sci. 117(S1) 243-262.

Moorthy K K 2010 ARFI and ICARB: Overview; Proceeding of the Project Review meeting, 9-10 June, 2010.

Nair V S, Moorthy K K, Babu S S, Narasimhulu K, Reddy L S S, Reddy R R, Gopal K R, Sreekanth V, Madhavan B L and Niranjan K 2008 Size segregated aerosol mass concentration measurements over the Arabian Sea during ICARB; J. Earth Syst. Sci. 117 315-323.

Nair V S, Krishna Moorthy K, Alappattu D P, Kunhikrishnan P K, George S, Nair P R, Suresh Babu S, Abish B, Satheesh S K, Tripathi S N, Niranjan K, Madhavan B L, Srikant V, Dutt C B S, Badarinath K V S and Reddy R R 2007 Wintertime aerosol characteristics over the Indo-Gangetic Plain (IGP): Impacts of local boundary layer processes and long-range transport; $J$. Geophys. Res. 112 D13205, doi: 10.1029/2006JD008099.

Pathak B, Bhuyan $\mathrm{P}$ K, Biswas J and Takemura T 2013 Long term climatology of particulate matter and associated microphysical and optical properties over Dibrugarh, north-east India and inter-comparison with SPRINTARS simulations; Atmos. Env., doi: 10.1016/ j.atmosenv.2012.12.032.

Pathak B and Bhuyan P K 2013 Absorbing and scattering properties of boundary layer aerosols over Dibrugarh, north east India; Int. J. Remote. Sens. (in press).

Pathak B, Bhuyan P K, Gogoi M M and Bhuyan K 2012 Seasonal heterogeneity in aerosol types over Dibrugarh, north-eastern India; Atmos. Env. 47 307-315, doi: 10.1016/j.atmosenv.2011.10.061.
Pathak B, Kalita G, Bhuyan K, Bhuyan P K and Moorthy K K 2010 Aerosol temporal characteristics and its impact on shortwave radiative forcing at a location in the north east of India; J. Geophys. Res. 115 D19204, doi: 10.1029/2009JD013462.

Pillai P S and Moorthy K 2001 Aerosol mass-size distributions at a tropical coastal environment: Response to mesoscale and synoptic processes; Atmos. Env. 35 40994112.

Ramanathan V et al. 2001 Indian Ocean experiment: An integrated analysis of the climate forcing and effects of the great Indo-Asian haze; J. Geophys. Res. 106(D22) 28,371-28,398, doi: 10.1029/2001JD900133.

Takemura T, Okamoto H, Maruyama Y, Numaguti A, Higurashi A and Nakajima T 2000 Global threedimensional simulation of aerosol optical thickness distribution of various origins; J. Geophys. Res. 105 17,85317,873 .

Takemura T, Nakajima T, Dubovik O, Holben B N and Kinne S 2002 Single-scattering albedo and radiative forcing of various aerosol species with a global threedimensional model; J. Climate 15 333-352.

Takemura T, Nozawa T, Emori S, Nakajima T Y and Nakajima T 2005 Simulation of climate response to aerosol direct and indirect effects with aerosol transportradiation model; J. Geophys. Res. 110 D02202, doi: 10.1029/2004JD005029.

Takemura T, Egashira M, Matsuzawa K, Ichijo H, O'ishi R and Abe-Ouchi A 2009 A simulation of the global distribution and radiative forcing of soil dust aerosols at the last glacial maximum; Atmos. Chem. Phys. 9 3061-3073.

Ward J H 1963 Hierarchical grouping to optimize an objective function; J. Am. Stat. Assoc. 58 236-244.

Weingartner E, Saathoff H, Schnaiter M, Strit N, Bitnar $\mathrm{B}$ and Baltensperger U 2003 Absorption of light by soot particles: Determination of the absorption coefficient by means of Aethalometers; J. Aerosol Sci. 34 1445-1463. 